\title{
II.-GHEMIGAL CHANGES IN THE BLOOD IN INFANTILE DIARRHOEA AND THE EFFEGT OF INTRAVENOUS ADMINISTRATION OF FLUID
}

\begin{abstract}
Although there is almost certainly some mechanism in the body which in most circumstances maintains a constant blood volume and concentration it is well recognized that great loss of body fluid or acidosis, or both, may upset this mechanism and lead to loss of water from the blood and increased concentration of its solid constituents ${ }^{1}$. In gastro-enteritis of infancy when the signs of dehydration may be severe it is probable that the blood as well as the tissues participate in the water loss. It is also well-known that the administration of fluid to patients with gastro-enteritis occupies an important if not central position in the therapeutic attack. In the present work an attempt has been made to study some of the changes that take place in the composition of the blood and to examine the effect of administration of fluid by intravenous injection of normal saline solution.

Unfortunately for various reasons it was not feasible to estimate blood volume directly; instead the concentration of blood constituents was determined. It may be assumed that the total amount of circulating protein in the blood remains constant, at any rate during short period observations. In this case the concentration of the serum proteins will give an indication of the degree of concentration or dilution of the plasma. The higher the percentage of serum proteins the greater the concentration of the plasma. The percentage of serum protein in the plasma was therefore used as a gauge of the degree of dehydration of the blood. This was determined by the Zeiss dipping refractometer for which only minute amounts of serum are required. In addition the blood chloride and non-protein nitrogen were estimated, the former because of the close association between chloride and water distribution in the body, the latter to afford some index as to the accumulation of waste products.
\end{abstract}

\section{The composition of the blood in gastro-enteritis}

The series of patients studied, all of whom were infants, can be divided into two groups:-(a) sixteen suffering from acute gastro-enteritis, and (b) fifteen marasmic infants with chronic diarrhoea. In each case the blood was first examined shortly after admission to hospital and prior to the administration of any parenteral fluid. 
Serum proteins. - In group (a) eleven of the patients had high values varying between $8 \cdot 46 \mathrm{gm}$. per cent. and $10 \cdot 19 \mathrm{gm}$. per cent. and five had between $6.96 \mathrm{gm}$. per cent. and $7.85 \mathrm{gm}$. per cent. Marriott ${ }^{1}$ and $\mathrm{Webb}^{2}$ found that in acute infantile diarrhoea the serum protein is usually raised well above the values obtained in healthy infants. Cohen and others ${ }^{3}$, on the other hand, found that in only four out of nine cases of acute infantile diarrhoea did the serum protein exceed $8 \mathrm{gm}$. per cent. The present results taken in conjunction with those of the last-named workers would indicate that in acute diarrhoeal conditions of infancy there is a tendency for the serum protein to be increased though this is not invariably the case. It would appear then that there is a tendency for the circulating plasma to lose water either into the tissues or into the gastro-intestinal tract.

In group (b) the serum protein was less than $8.0 \mathrm{gm}$. per cent. in all but one case, being as low as $4.92 \mathrm{gm}$. per cent. in one patient. These results are in accord with the findings of Courtney and Fales ${ }^{4}$ and Marriott ${ }^{5}$. The last investigator also found that the percentage volume of red cells and percentage haemoglobin were reduced. This he suggested may be due either to the presence of too much water in the circulating blood or to disappearance of serum protein, red cells and haemoglobin. Thus while it is reasonable to assume in acute gastro-enteritis that a raised value for serum protein is indicative of loss of water the opposite conclusion cannot be drawn from a diminished value in chronic diarrhoeal conditions, since it may be an expression of many diverse factors such as passage of water to and from the tissues, previous malnutrition with its concomitant reduction of serum proteins, and excessive destruction of serum proteins.

Non-protein nitrogen._-_GRoup (a). In ten patients the non-protein nitrogen varied between $47 \cdot 1$ and $97 \cdot 4 \mathrm{mgm}$. per cent. and in three between $37 \cdot 3$ and $42.7 \mathrm{mgm}$. per cent. and in only one was it well within normal limits at $21.7 \mathrm{mgm}$. per cent. These results support the view of Cohen and others $^{3}$ that in most patients suffering from acute infantile diarrhoea there is a definite increase in the non-protein nitrogen of the blood. These uuthors also think that a close relationship exists between the level of the non-protein nitrogen and the degree of toxaemia. Hoag and Marples ${ }^{6}$, however, obtained a definite increase in the non-protein nitrogen value only when the patient was moribund. The different results are probably to be attributed to differences in the degree of toxaemia and of dehydration in the various groups of patients.

The increase in non-protein nitrogen in acute infantile diarrhoea has been interpreted in various ways. Schloss ${ }^{7}$ has suggested that it is the result of diminished renal action consequent on a depleted store of available fluid and Marriott's $\mathrm{s}^{5}$ view was that there was also an accelerated destruction of tissue protein. Probably both factors are present and the level of the non-protein nitrogen depends on whether or not sufficient fluid is available to carry away the products of tissue breakdown which almost certainly is increased. 
Group (b). In all but four cases in which the non-protein nitrogen varied between 50.0 and $56.0 \mathrm{mgm}$. per cent. it was within normal limits. Nobécourt ${ }^{8}$ found an increase in the urea content of the cerebro-spinal fluid in this type of case but Rohmer and others ${ }^{9}$ obtained normal values. The smaller incidence of high non-protein nitrogen values in chronic diarrhoea than in the acute disease is probably due to the fact that in many cases the toxaemia is not so marked in chronic as in the acute condition. Furthermore the fact that the serum protein concentration is not increased in the patients with chronic diarrhoea indicates that loss of water from the blood is not a feature so that sufficient water is presumably available for the excretion of any excess of waste products that may be produced.

Chloride.-Group (a). Of the nine patients in whom the blood chloride was estimated only two had high values the other figures falling within normal limits. Similar observations have been reported by other workers $6,10,11,12$.

Group (b). In this group the values for blood chloride varied between $59 \cdot 4$ and 80.3 c.c. $\mathrm{N} / 10$ per cent., i.e., were either low or within normal limits. Courtney and Fales $^{4}$ have demonstrated that in athreptic infants the blood chloride is often low but may be normal or even high. The low values frequently found in chronic diarrhoea are probably the result of long continued malnutrition and loss of chloride in the faeces and vomitus, and the occasional high values may be an indication that the condition has taken on an acute phase with its attendant metabolic disturbance.

The blood chemistry pictures differ in acute gastro-enteritis and chronic diarrhoeal conditions. In the former the serum protein, non-protein nitrogen and chloride all tend to be high while in the latter low values are frequently obtained. Assuming that high serum protein indicates undue concentration of blood plasma, in other words a loss of water from the circulating blood it would appear from the tendency of blood chloride to be high that the water leaves the blood stream without its full quota of chloride. In chronic diarrhoea, on the other hand, when the plasma concentration is reduced as shown by the low values for serum protein the blood chloride tends to be on the low side so that here water enters the blood without its full quota of chloride. Accordingly, it would appear that in acute gastro-enteritis the primary need is for fluid to reduce the concentration of the blood and to act as a vehicle for the excretion of the accumulated waste products whereas in chronic diarrhoea the essential requirement is to enrich the diluted blood by a supply of protein and minerals.

\section{The effect of parenteral fluid administration on the blood constituents}

It has been demonstrated by many observers ${ }^{3,6,13}$ that as the result of fluid administration to infants suffering from diarrhoea and vomiting, there results an improvement in their general condition; the kidneys begin to 
secrete urine, the dehydration becomes less marked and the acidosis disappears. How these changes are brought about, however, is as yet imperfectly understood. There at present exists much confusion in the current ideas of the redistribution of water and chloride following the parenteral administration of fluid.

Greene and Rowntree ${ }^{14}$ have shown that, when the volume of the fluid in the circulation of experimental animals is increased by forced water administration, much of the extra fluid introduced escapes from the circulation with great rapidity. In saline infusion experiments on dogs, Adolph, Gerbasi and Lefore ${ }^{15}$ demonstrated similar rapid losses of fluid and also observed that chloride left the circulation even more rapidly than water. On the other hand, Davis ${ }^{16}$ found in dogs that the vascular system did act as a fluid reservoir for he observed that the blood remained diluted for a period of five hours after infusion. The maximum blood dilution was usually not reached for a period of one hour, this initial dilution being immediately followed by concentration and later by further dilution.

The object of the present investigation was to determine the effects in infants of intravenous administration of fluid, given for therapeutic purposes, on the blood concentration as indicated by the level of the serum protein. For this purpose the serum protein was determined in infants before and at intervals after intravenous injection of saline-glucose solution. In all, three groups of patients were studied. These comprised (1) infants without any gastro-intestinal symptoms; (2) infants with acute gastroenteritis; and (3) infants with chronic diarrhoea.

Group I - From the results in table 1, it will be seen that the nonprotein nitrogen showed a slight fall over the three-hour period during which TABLE 1

The NON-PRotein Nitrogen OF THE BLOOD IN MGM. PER CENT. AFTER INTRAVENOUS SALINE

\begin{tabular}{|c|c|c|c|c|c|c|}
\hline \multirow{2}{*}{ Type of Case } & \multirow{2}{*}{ Name } & \multicolumn{5}{|c|}{ Time after injection } \\
\hline & & BEFORE & $\frac{1}{2}$-HOUR & 1 HOOR & 2 HOURS & 3 HOURS \\
\hline \multirow[t]{2}{*}{ Non-diarrhoeal } & $\begin{array}{l}\text { J. M. } \\
\text { J. G. }\end{array}$ & $\begin{array}{l}38 \cdot 2 \\
30 \cdot 7\end{array}$ & $\begin{array}{l}37 \cdot 8 \\
30 \cdot 9\end{array}$ & $\begin{array}{l}37 \cdot 8 \\
27 \cdot 6\end{array}$ & $\begin{array}{l}37 \cdot 3 \\
25 \cdot 2\end{array}$ & $\begin{array}{l}35 \cdot 5 \\
25 \cdot 5\end{array}$ \\
\hline & Average & $34^{\circ} \tilde{5}$ & $34 \cdot 3$ & $32 \cdot 7$ & $31 \cdot 2$ & $30 \cdot 5$ \\
\hline \multirow[t]{2}{*}{ Acute diarrhoea } & $\begin{array}{l}\text { A. J. } \\
\text { R. M. }\end{array}$ & $\begin{array}{l}67 \cdot 5 \\
39 \cdot 3\end{array}$ & $\begin{array}{l}57 \cdot 4 \\
39 \cdot 7\end{array}$ & $\begin{array}{l}64 \cdot 1 \\
40 \cdot 3\end{array}$ & $\begin{array}{l}59 \cdot 5 \\
35 \cdot 2\end{array}$ & $\begin{array}{l}58 \cdot 8 \\
37 \cdot 3\end{array}$ \\
\hline & Average & $53 \cdot 4$ & $48 \cdot 5$ & $52 \cdot 2$ & $47 \cdot 3$ & $48 \cdot 0$ \\
\hline \multirow[t]{2}{*}{ Chronic diarrhoea } & $\begin{array}{l}\text { W. A. } \\
\text { A. M. } \\
\text { P. H. } \\
\text { C. D. } \\
\text { A. H. }\end{array}$ & $\begin{array}{l}41 \cdot 3 \\
51 \cdot 0 \\
36 \cdot 8 \\
27 \cdot 7 \\
56 \cdot 9\end{array}$ & $\begin{array}{l}28 \cdot 5 \\
42 \cdot 0 \\
37 \cdot 8 \\
29 \cdot 1 \\
49 \cdot 0\end{array}$ & $\begin{array}{l}28 \cdot 7 \\
43 \cdot 5 \\
32 \cdot 7 \\
27 \cdot 5 \\
45 \cdot 0\end{array}$ & $\begin{array}{l}29 \cdot 4 \\
41 \cdot 7 \\
29 \cdot 9 \\
27 \cdot 4 \\
47 \cdot 6\end{array}$ & $\begin{array}{l}29 \cdot 0 \\
40 \cdot 9 \\
29 \cdot 8 \\
27 \cdot 6 \\
42 \cdot 7\end{array}$ \\
\hline & Average & $42 \cdot 7$ & $37 \cdot 3$ & $35 \cdot 5$ & $35 \cdot 0$ & $34 \cdot 0$ \\
\hline
\end{tabular}


the examinations were continued. The total serum protein, however, showed rather characteristic and remarkable variations, more marked in some cases than in others (table 2). Thirty minutes after the injection,

TABLE 2

SERUM PROTEIN IN GM. PER CENT. AFTER INTRAVENOUS SALINE

\begin{tabular}{|c|c|c|c|c|c|c|c|}
\hline \multirow{2}{*}{ TyPe of Case } & & \multirow{2}{*}{ Name } & \multicolumn{5}{|c|}{ TIME AFTER INJECTION } \\
\hline & & & BeFORE & $\frac{1}{2}$ HOUR & 1 IOUR & 2 HOURS & 3 HOURS \\
\hline \multirow[t]{5}{*}{ Non-diarrhoeal } & ... & J. M. & $7 \cdot 51$ & $6 \cdot 40$ & $7 \cdot 59$ & $6 \cdot 63$ & $7 \cdot 09$ \\
\hline & & J. G. & $6 \cdot 92$ & $5 \cdot 92$ & $5 \cdot 96$ & $5 \cdot 40$ & $5 \cdot 58$ \\
\hline & & J. N. & $6 \cdot 4 \pi$ & $6 \cdot 03$ & $6 \cdot 55$ & $6 \cdot 00$ & $6 \cdot 18$ \\
\hline & & C. S. & $7 \cdot 74$ & $7 \cdot 22$ & $7 \cdot 83$ & $7 \cdot 11$ & $7 \cdot 17$ \\
\hline & & Average & $7 \cdot 16$ & $6 \cdot 39$ & $6 \cdot 98$ & $6 \cdot 29$ & $6 \cdot 51$ \\
\hline \multirow[t]{7}{*}{ Acute diarrhoea } & $\ldots$ & M. McL. & $7 \cdot 48$ & $7 \cdot 02$ & $7 \cdot 09$ & $6 \cdot 77$ & $6 \cdot 79$ \\
\hline & & I. M. & $10 \cdot 19$ & $8 \cdot 32$ & $9 \cdot 07$ & $9 \cdot 14$ & $8 \cdot 64$ \\
\hline & & V. F. & $7 \cdot 85$ & $6 \cdot 96$ & $6 \cdot 98$ & $7 \cdot 15$ & $7 \cdot 12$ \\
\hline & & A. J. & $8 \cdot 91$ & $7 \cdot 65$ & $8 \cdot 71$ & $8 \cdot 56$ & $8 \cdot 62$ \\
\hline & & H. $\mathrm{McN}$. & $9 \cdot 39$ & $7 \cdot 96$ & $8 \cdot 26$ & $8 \cdot 91$ & $8 \cdot 69$ \\
\hline & & R. M. & $7 \cdot 26$ & $i \cdot 14$ & $6 \cdot 49$ & $6 \cdot 85$ & $6 \cdot 36$ \\
\hline & & Average & $8 \cdot 52$ & $7 \cdot 34$ & $7 \cdot 77$ & $7 \cdot 90$ & $7 \cdot 69$ \\
\hline \multirow[t]{9}{*}{ Chronic diarrhoea } & ... & W. A. & 7.78 & $6 \cdot 55$ & $6 \cdot 85$ & $6 \cdot 83$ & $7 \cdot 96$ \\
\hline & & A. M. & $6 \cdot 70$ & $6 \cdot 27$ & $6 \cdot 72$ & $6 \cdot 29$ & $6 \cdot 42$ \\
\hline & & P. H. & $6 \cdot 09$ & $4 \cdot 92$ & $5 \cdot 29$ & $5 \cdot 60$ & $5 \cdot 38$ \\
\hline & & C. D. & $4 \cdot 92$ & $4 \cdot 54$ & $4 \cdot 84$ & $4 \cdot \tilde{0} 0$ & $4 \cdot 48$ \\
\hline & & A. $\mathrm{H}$. & $6 \cdot 49$ & $5 \cdot 79$ & $5 \cdot 64$ & $5 \cdot 36$ & $5 \cdot 53$ \\
\hline & & W. McF. & $7 \cdot 53$ & $6 \cdot 36$ & $8 \cdot 05$ & $7 \cdot 17$ & $6 \cdot 85$ \\
\hline & & M. McI. & $6 \cdot 68$ & $6 \cdot 34$ & $7 \cdot 39$ & $6 \cdot 88$ & $6 \cdot 72$ \\
\hline & & B. $\mathrm{M}$. & $6 \cdot 29$ & $5 \cdot 65$ & $5 \cdot 81$ & $5 \cdot 05$ & $5 \cdot 58$ \\
\hline & & Average & $6 \cdot 56$ & $5 \cdot 8 x$ & $6 \cdot 32$ & $5 \cdot 96$ & $6 \cdot 12$ \\
\hline
\end{tabular}

there was a definite reduction of serum protein which most probably would have been still lower if specimens had been removed immediately after completing the saline injection. After the lapse of one hour the percentage of serum protein had risen in most cases to near, and in some cases above 
the pre-infusion level. At two hours there was a fall which was more marked in some cases than in others, while at three hours a rise was again noted. It also appears probable that if specimens had been removed after the lapse of four to five hours, the serum proteins would have shown a reading very near to that of the pre-infusion level. These fluctuations in the serum proteins over such a short interval are probably to be explained by (1) alterations in the distribution of fluid between the circulation and the tissue spaces and (2) excretion of some fluid by the kidneys.

Miller and Pointdexter ${ }^{17}$ have also demonstrated in dogs that the serum protein fell immediately after saline injections, commenced rising after fifteen minutes, but did not reach the pre-injection level at the end of one hour. Very similar findings are reported by Onozaki ${ }^{18}$ who studied the serum protein values of rabbits for a period of seven hours after the intravenous injections of isotonic saline. He found that the serum protein concentration usually fell immediately after the injection, began rising at once and attained a value slightly lower than the pre-injection figure at the end of one hour, after which it again fell and did not quite reach the preinjection value at the end of seven hours. He also mentions that similar changes were noted when the haemoglobin in rabbits was estimated after saline injections. It is evident therefore that the present results with infants closely resemble those obtained experimentally in animals.

Group 2. Acute infantile diarrhoea.- In this group the non-protein nitrogen was slightly reduced; in one of the two cases the reductions amounted to $8 \mathrm{mgm}$. per cent. (see table 1). Although the initial fall of serum protein immediately after the injection was just as marked as in the case of group 1 the rise at one hour was not so marked and the secondary fall if it did occur was sometimes delayed till the third hour (table 2). The variations of serum protein in these patients were thus less marked than in group 1, so that if it is accepted that the concentration of serum protein serves as an index of plasma volume concentration ${ }^{19}$ it must be concluded that in patients with acute infantile diarrhoea the blood plasma remains diluted for a longer period than in cases in which dehydration is not present. This is in accord with the results obtained by Davis ${ }^{16}$ who showed that in dogs suffering from the effects of dehydration the ability of the blood to hold both isotonic saline and glucose was greater than that found in normal animals.

The blood pressure according to Blalock, Beard and Theiss ${ }^{20}$ and Adolph and Lefore ${ }^{21}$ plays an important part in the redistribution of fluids during saline injections in animals. The latter investigators discovered that more fluid passed into the tissue spaces when the blood pressure was high than when it was low. It is possible that the slow passage of fluid from the circulation in cases of acute infantile diarrhoea may be due to a diminished blood pressure, although $\mathrm{Hill}^{22}$ maintains that there is no diminution of the blood pressure in these infants. Attempts were made to estimate the blood pressure in several of the present series of patients but in only one was this successfully accomplished, and in this case the reading appeared to be low. 
Group 3. Chronic infantile diarrhoea.-After saline injection the nonprotein nitrogen in all cases except one showed a definite fall during the period of observation (see table 1). In the exceptional case the non-protein nitrogen, low at the beginning, remained at a constant level during the three-hourly period after saline injection. The variations of serum protein in this group were, however, not at all characteristic (see table 2). Some patients exhibited variations somewhat similar to those found in infants without gastro-intestinal symptoms (group 1), but with a much smaller range; others showed variations similar to those found in group 2.

\section{The effect of calcium on the fate of fluid given intravenously}

It has long been known that calcium is one of the substances which diminish the permeability of cells to water. A few studies were therefore made in an attempt to determine the effect on the serum of addition of calcium gluconate to the injected solution.

Group 1.-Administration of calcium to infants in whom no signs of dehydration were present caused little change in the fluctuation of serum protein after injection of saline (table 3).

\section{TABLE 3}

Serum protein in GM. PER Cent. after intravenous Saline CONTAINING CALCIUM GLUCONATE

\begin{tabular}{|c|c|c|c|c|c|c|}
\hline \multirow{2}{*}{ Type of Case } & \multirow{2}{*}{ Name } & \multicolumn{5}{|c|}{ Time after injection } \\
\hline & & Before: & $\frac{1}{2}$ Hotr & 1 hove & 2 Hovis & 3 novrs \\
\hline \multirow[t]{5}{*}{ Non-diarrhoeal } & C. S. & $7 \cdot 35$ & $6 \cdot 47$ & $6 \cdot 63$ & $6 \cdot 34$ & 6.68 \\
\hline & C. S. & $7 \cdot 35$ & $6 \cdot 51$ & $6 \cdot 79$ & $6 \cdot \% 0$ & $6 \cdot 42$ \\
\hline & J. N. & $7 \cdot 13$ & $6 \cdot+2$ & $6 \cdot 79$ & $6 \cdot 18$ & $6 \cdot 29$ \\
\hline & C. S. & 7.65 & $7 \cdot 39$ & $7 \cdot 44$ & $7 \cdot 11$ & $7 \cdot 24$ \\
\hline & A verage & $7 \cdot 37$ & 645 & 6.91 & 6.58 & $6 \cdot 66$ \\
\hline \multirow[t]{3}{*}{ Acute diarrhoea } & B. I. & $8 \cdot 82$ & $7 \cdot 72$ & $8 \cdot 91$ & $9 \cdot 42$ & $9 \cdot 34$ \\
\hline & M. 13. & $9 \cdot 03$ & $7 \cdot 57$ & $8 \cdot 46$ & $8 \cdot 35$ & $8 \cdot 37$ \\
\hline & Average & $8 \cdot 92$ & $7 \cdot 64$ & $8 \cdot 68$ & 888 & $8 \cdot 85$ \\
\hline \multirow[t]{3}{*}{ Chronic diarrhoea } & C. B. & $8 \cdot 62$ & $8 \cdot 58$ & $9 \cdot 12$ & $9 \cdot 01$ & $8 \cdot 73$ \\
\hline & B. M. & $6 \cdot 38$ & $6 \cdot 20$ & $6 \cdot 47$ & $6 \cdot 36$ & $6 \cdot 63$ \\
\hline & Average & $7 \cdot 50$ & $7 \cdot 39$ & $7 \cdot 79$ & $7 \cdot 68$ & $7 \cdot 68$ \\
\hline
\end{tabular}


Groups 2 and 3.-Four infants, two with acute and two with chronic diarrhoeal conditions, were given calcium gluconate together with glucose and saline. Clinically the addition of calcium gluconate to the injection fluid did not appear to have any special effect on the patients' general condition. In both chronic cases the initial protein fall was minimal after injection, at one hour there was a rise to a value higher than the preinjection level and then a gradual fall, so that three hours after injection the reading was still greater than in the first specimen removed (table 3).

In the two patients suffering from acute infantile diarrhoea, one showed a large and significant fall of serum protein as the result of the injection, followed by a steady rise until at two hours it reached a value greatly in excess of the protein level in the pre-injection specimen. At three hours the protein value showed a slight fall but still remained at a reading greater than the initial value of $8.82 \mathrm{gm}$. per cent. (table 3). Similar but not so marked findings were observed in the other case. It would thus appear that in infantile diarrhoea, when calcium gluconate has been given along with glucose and saline, the serum proteins exhibit alterations peculiar to the individual patient, but on the whole it would appear that in contrast to the findings in group 1 the presence of calcium in the fluid injected facilitates the transference of fluid from blood to tissues.

\section{Discussion}

The serum protein variations, occurring over a period of one to five hours after fluid injections in normal infants, appear to be similar to those described by Miller and others ${ }^{17}$ in animals. During such a short space of time, the rapid and marked alteration of serum protein is in all probability due to alterations in the plasma volume. It would appear that, as the result of saline injection, there immediately occurs an increase of the plasma volume which gradually diminishes until at one hour, in most cases, it is smaller than the volume previous to the saline administration. This diminution in volume can only be explained by the fact that immediately after the injection the additional fluid is removed from the circulation. Most of it must pass to the tissue spaces and the water depots of the body as it would be impossible for the kidneys to deal with such a quantity of fluid within the short space of one hour. In several infants, it was observed that at one hour the serum protein value was higher than before the injection was given, indicating that more fluid had left the circulation than had been administered. It is thus evident that the circulation, in an attempt to remove the excess fluid, oversteps the mark and loses not only that introduced but also fluid previously in the blood stream. At two hours however, due to passage of fluid back from the tissues to the circulation, the serum protein shows a fall as compared with the value at one hour, but at three hours the plasma volume returns to the vicinity of its pre-injection level.

These findings indicate that, as the result of fluid injections in normal infants, a to-and-fro movement of fluid takes place between the blood plasma 
and the water depots of the body until after the lapse of three to four hours, the normal water content of the plasma is reached and maintained. This is probably due to the establishment of increased renal activity and removal of surplus fluid.

The mechanism regulating the passage of fluid from one tissue to another is imperfectly understood, but the finding of Blalock and others ${ }^{20}$ that, in dogs with a lowered blood pressure, fluid passed much more slowly from the circulation into the tissue spaces than in dogs with a normal blood pressure, would seem to indicate the importance of blood pressure as one of the regulating factors. There is also no doubt, that osmotic action and the capacity of the water depots and tissue spaces of the body to absorb fluid, take a part in initiating these movements.

In patients suffering from acute infantile diarrhoea there also occurs a definite increase in the plasma volume as the result of saline and glucose injections---shown by the fall of serum protein at the half hour period after injection--but the plasma remains diluted for longer than occurs in normal infants. It is also evident that the amount of fluid passed either in the tissues during the first hour or back into circulation during the second hour, is never as great as occurs in patients without gastro-intestinal disturbances. The slower and smaller fluid alterations between the circulation and the tissues of acute diarrhoea are probably to be attributed to (a) a lowered blood pressure ${ }^{20,21}$; (b) increased affinity of the circulation for fluid ${ }^{16}$; (c) diminished affinity to the tissues for fluid; or (d) some other abnormality such as alteration of osmotic pressure. The increased concentration of blood constituents which is known to occur in most cases of acute infantile diarrhoea ${ }^{1}$ might readily result in an increased affinity of the circulating blood for the administered fluid.

In chronic infantile diarrhoea it would appear that in some patients the normal movements of fluid between the circulation and the tissues is also upset, but to a much less marked extent than occurs in acute cases. In others, however, the movements appear even more exaggerated than those found in infants without diarrhoea.

Addition of calcium gluconate to the saline and glucose solution had in infants without diarrhoea (group 1) little effect on the fluctuations of fluid between the tissues and the blood plasma. In three of the four acute and chronic diarrhoea cases the use of the calcium gluconate seemed to accelerate the passage of the injected fluid from the circulation to the tissue spaces. It is possible that this might be the result of the well-known action of calcium in increasing the efficiency of the heart's action. The presence of calcium in the injected fluid, therefore, may be of advantage in promoting the transfer of fluid to the tissue spaces and preventing its over-rapid return to the circulating blood. It is also possible that in this way more fluid could be administered without causing embarrassment to the circulation. 


\section{Summary}

The serum protein and non-protein nitrogen and chloride of whole blood were estimated in cases of acute gastro-enteritis and chronic diarrhoea. In the former the serum protein, non-protein nitrogen and chloride all tended to be high while in the latter low values for protein and chloride were frequently obtained and the non-protein nitrogen generally fell within normal limits.

The significance of these findings is discussed and it is suggested that in acute gastro-enteritis there is a loss of water from the circulating blood and that the water leaves the blood stream without its full quota of chlorine. In chronic diarrhoea it would appear that water enters the blood without its full quota of chlorine.

As a result of saline and glucose injections characteristic alterations occur in the serum protein of normal infants. In infants with acute gastroenteritis these alterations are much less marked and it is concluded that the blood plasma remains diluted for much longer than in the infant without dehydration.

The results of adding calcium gluconate to the injected fluid suggest that in infantile diarrhoea calcium gluconate may be of some benefit in accelerating the movement of fluid from the circulation to the tissue spaces.

\section{REFERENCES}

1. Marriott, W. McK., Amer. J. Dis. Child., Chicago, 1920, XX, 461.

2. Webb, C. H., ibid., 1932, XLIV, 1239.

3. Cohen, H., Miller, P. R., \& Kramer, B., J. Pediat., St. Louis, 1933, III, 299.

4. Courtney, A. M., \& Fales, H. L., Amer. J. Dis. Child., Chicago, 1917, XIV, 202,

5. Marriott, W. McK., Physiol. Reviews, Baltimore, 1923, III, 275.

6. Hoag, L. A., \& Marples, E., Amer. J. Dis. Child., Chicago, 1931, XLII, 291.

7. Schloss, O. M., ibid., 1918, XV, 165.

8. Nobécourt, P., Arch. Méd. Enfants, Paris, 1913, XVI, 801.

9. Rohmer, P., Welsdorf, P., \& Dreyfus, P., Ref. franç. de Pediat., Paris, 1927, III, 277.

10. Hartman, A. F., Amer. J. Dis. Child., Chicago, 1928, XXXV, 557.

11. Maizels, M., \& MeArthur, C. B., Quart. J. Med., Oxford, 1930, XXIII, 171.

12. Hamilton, R., Kajdi, L., \& Meeker, D., Amer. J. Dis. Child., Chicago, 1928, XXXVIII, 314.

13. Marples, E., Cohen, H., \& Galmo, H., ibid., 1934, XLVII, 331.

14. Greene, C. H., \& Rowntree, L. G., Amer. J. Physiol., Baltimore, 1927, LXXX, 209.

15. Adolphe, E. F., Gerbasi, M. J., \& Lefore, M. J., Amer. J. Physiol., Baltimore, 1934, CVII, 647.

16. Davis, H. A., Proc. Soc. Exp. Biol. \& Med., Utica, N.Y., 1934, XXXII, 210.

17. Miller, J. R., \& Pointdexter, C. A., J. Lab. \& Clin. Med., St. Louis, 1932, XVIII, 287.

18. Onozaki, N., Tohoku J. Exp. Med., Tohoku, 1935, XXV, 1.

19. Lee, D. H. K., \& Mulder, A. G., J. Physiol., London, 1935, LXXXIV, 4.

20. Blalock, A., Beard, J. W., \& Theiss, C., J. Clin. Invest., New York, 1932, XI, 267.

21. Adolph, E. F., \& Lefore, M. J., Proc. Soc. Exp. Biol. \& Med., Utica, N.Y., 1931, XXVIII, 963.

22. Hill, H. K., Arch. Pediat., New York, 1913, XXX, 588. 